\section{French science}

\section{Good times are here again}

THE French socialist party, which forms the present government in France, took a knock at the polls last weekend when rightwing parties scored 58 per cent of the vote in local elections. Of course, the French economy took its dive later than others in the West, and the electorate blames it on the new government. They may be right. But President Mitterrand's administration does have at least one feather in its cap science - and it was seen to be waving it vigorously last week before the elections.

According to a communique from the council of ministers last week, French research and development spending has leapt more than a fifth in real terms since 1980 , from 1.85 per cent of gross national product in 1980 to 2.25 per cent this year. Basic science may not have done so well (against a rising dollar) but "France has thus begun to regain its position among its principal partners and foreign competitors", the communiqué claimed. The benefits would come later, the investment "furnishing a solid base or the second step in the politics of industrial renovation"'.

The trouble is that the first step has been restructuring and unemployment. The electorate, unfortunately for the government, observes decline now more clearly than growth later. Nevertheless, the government has again pinned its colours to scientific growth at an important moment, when the "law for science", the creation of the first socialist science minister, JeanPierre Chevènement, nears the end of its term.

To replace it, Hubert Curien, the present science minister, promises a new law to be presented to the National Assembly in the spring, while the council of ministers is announcing that "research and development are, in effect, the keys to the modernization of our country". Auspicious times for French science appear to be here again.

Yet there are problems. Curien has been making an assessment of the successes and failures of science policy over the past three years, and describes it as "incontestably positive'". But industry has been slow to invest in research; the new labour rights of researchers (which are supposed to increase mobility) have only just come into force, and many basic research laboratories are suffering from under-equipment and too few hard dollars for materials and apparatus. French computing power is also way behind the competitors, despite a decision last year to allow laboratories after ten years' moratorium - to buy foreign machines. Much cash was also wasted on ill-conceived national technology programmes.

The necessary structural reforms have now been accomplished, says Curien; the great revolution has been the acceptance by

\section{Italian biotechnology}

a largely left-wing university system of the need to cooperate with industry and by industry of universities as partners. The stage is set for real development, Curien would claim. "The decline of Europe in relation to the United States and Japan is not written in history", he wrote last week in the newspaper Le Monde. And France must develop with Europe: "Is science not one of the best cements for a still fragile but indispensable European cooperation?", he asks.

In France, a commission has been set up to study the proposed law for science. But already the council of ministers has promised scientists several benefits:

- An increase in cash available for laboratory equipment.

- A long-term policy for training and employment in research and development.

- The establishment of research more widely in industry.

- Continuance of the "great programmes of technological development" such as space, aeronautics, energy and the oceans. - At the same time, reinforcement of the assessment of these programmes and other action so that corrections can be applied when things go wrong.

- Improvement of tax and other financial incentives to industry and to research.

- Continuance of the "strong priority" given to research and development.

Robert Walgate

\title{
Planning to catch up rivals
}

\section{Rome}

A NEW centre for biotechnology research and development is being founded at Pomezia, $45 \mathrm{~km}$ south of Rome, by Menarini SaS, the Florence-based pharmaceutical company. Dr Alberto Aleotti, president of Menarini, says the company is investing 28,000 million lire in the new biotechnology centre.

The first goal of the centre will be the manufacture of TPA (tissue plasminogen activator) and its derivatives for human pharmaceutical purposes, using recombinant DNA technology developed by Creative Biomolecules, a California corporation founded in 1982 by the 36-year-old Italian, Roberto Crea, and Charles M. Cohen.

The agreement between Menarini and Creative Biomolecules is aimed at the production of an economic drug for the international market. The Pomezia team will include researchers from Italy, the United States and Britain. The first TPA for chemical and biological evaluation is expected in the summer. Crea, acknowledging that his project is not the first in the field - Genetech first cloned TRA in 1982 - says its objectives are superior.

Inaugurating the Menarini centre (and the toxicology research facility on the same site), Italian minister of research Luigi Granelli pointed to several encouraging signs of development in Italian biotechnology by way of international cooperation. The international genetic engineering centre of the United Nations Industrial Development Organization, to be based at Trieste, is one of these. But Granelli added that developments in this field in Europe as a whole are still not a sufficient counter to developments in Japan and the United States, perhaps because governments see their interests as stronger than supra national ventures.

Italian biotechnology is in part held back by the lack of venture capital, with the result that most of the companies involved are either well established in some related field such as pharmaceuticals or are public enterprises. The companies with declared interests include Farmitalia-Carlo Erba (Montedison group, now under the umbrella of Erbamont), Lepetit and Serono. Sorin Biomedica (wholly owned by Fiat), Farmitalia and various companies of the ENI group have declared an interest in protein chemistry; Sclavo, an ENI company, plans to produce beta-interferon. Biotechnology in agriculture is quite advanced at ENEA, the public corporation for nuclear and alternative sources of energy, and Assoreni (ENI group) has interests in agricultural biotechnology.

University researchers have been drawn into biotechnology in various ways. Thus the multinational Roche facility at Milan has an agreement with the Pharmacology Institute of the University of Milan, headed by Professor Rodolfo Paoletti, for applications to molecular neurobiology. The Italian Society for Biotechnology (SIB) has signed a convention with IASM, the public sponsor of development in the south of Italy, and with FINAM, a financial holding for agriculture, to set up a centre for biotechnology transfer in the south.

The first objective of the centre will be to evaluate the degree of innovation in small and medium-size industries so that by the end of 1985 agricultural experiments on a pilot-plant scale may be started.

Projects sponsored by the Consiglio Nazionale delle Ricerche (CNR) have modest achievements to report. While the CNR genetic engineering programme, launched in 1982 with 20,000 million lire has so far recruited only a few participants among Italian industries, a 1980 project (due to finish this year) on fine chemicals under the direction of Professor Luciano Caglioti has worked with 500 different entities. So far, the project has published 1,800 scientific papers and produced 150 patents, some of which have already gone into production.
Paola de Paoli 